\title{
Morphological Features of Cell Death through Microscopic View
}

\author{
Babak Beikzadeh ${ }^{1 *}$, Nowruz Delirezh ${ }^{1}$ \\ ${ }^{1}$ Department of Microbiology, Faculty of Veterinary Medicine, Urmia University, Urmia, Iran. Phone: (+) 984412972648 , Fax: (+) 98441 \\ 3440199, E-mail: bbeikzadeh@live.com \\ Received: 27 Jul 2014 Revised: 5 Sep $2014 \quad$ Accepted: 15 Sep 2014
}

Please cite this article as: Beikzadeh B, Delirzeh N. Morphological Features of Cell Death through Microscopic View. Res Mol Med. 2014; 2 (4): 1-2

Cells are active components in their environment and constantly adjusting their performance to improve extracellular milieu changing. This approach is reflected their tends of maintaining intracellular homeostasis. When the cells encounter stress or pathologic stimuli, they can undergo a new manner (adaptation) and new steady state for achieving viability and function. If the external stress is exceeded or adaptive capability continues, cell injury develops $(1,2)$. Cells injury is engaged in a process that is reversible or irreversible. Injury is reversible when the stimuli are limited and removed. Only in the persistent stress or pathologic stimuli a reversible phase converted into irreversible phase (point-of-noreturn) and causes cell death (3). However, cell death is the most important step in embryogenesis, organ development, hemostasis and also the evolution of disease in any organ (1). The most classifications of mammalian cell death are apoptosis and necrosis.
Apoptosis occurs naturally in many situations and helps to eliminate the cells that lost their efficiency.

Cells undergoing apoptosis show biochemical events lead to cell changes (morphology) and death $(4,5)$. These features include cell blebbing, shrinkage, chromatin condensation and nuclear fragmentation. Unlike necrosis, which is a pathologic cell death, apoptotic cells release cell fragment called apoptotic bodies $(1,6)$. This image was taken with light microscopes (Nikon, TE2000 inverted microscopes), peripheral blood monocytes during 13 days culture initially change into macrophage-like cells and then due to lack of nutrition materials and a high level of toxic substance, to undergo cell death. The morphological changes as mention above (Fig1 legend) approved apoptosis process and cell death. However, sometimes the end stage of apoptosis accompanied by necrosis and it is not possible to distinguish them from the microscopic view.

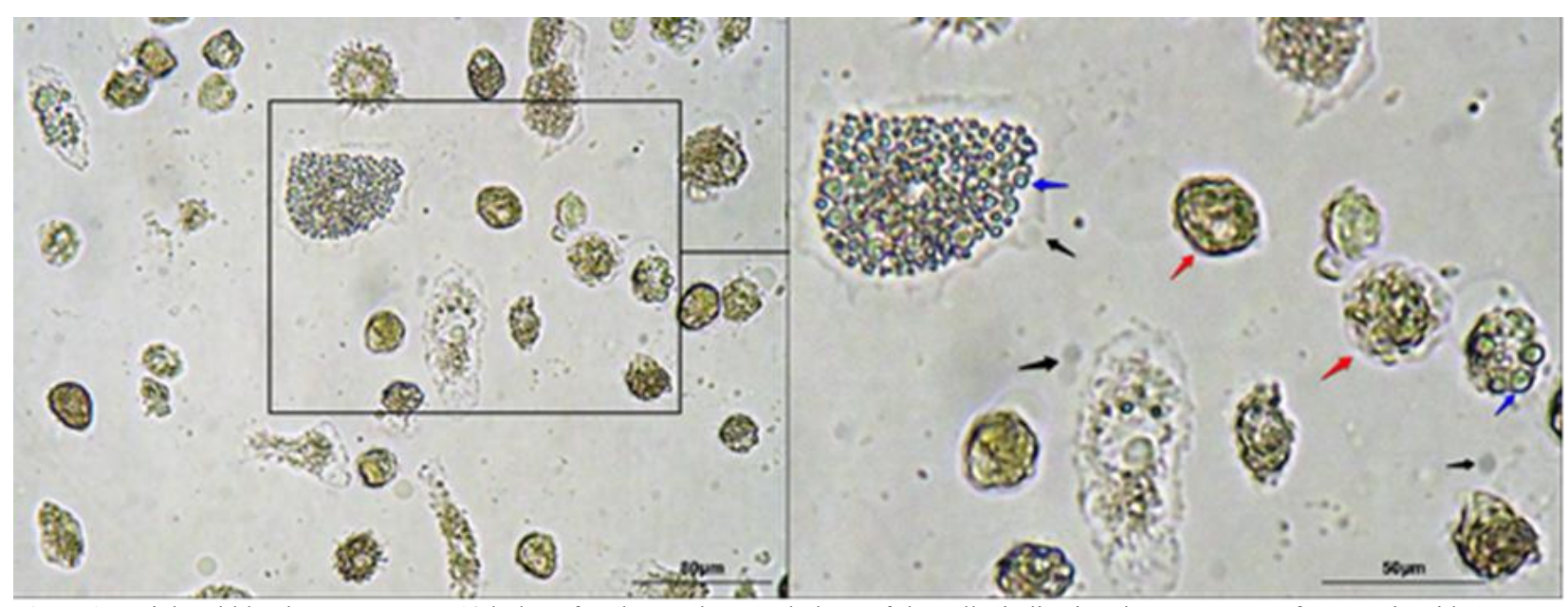

Figure1. Peripheral blood monocytes on 13th day of culture. The morphology of the cells, indicating the occurrence of apoptosis with features such as blebbing (blue arrows), cell shrinkage (red arrows) and release apoptotic bodies (black arrows), magnification $40 \times$.

\section{Acknowledgments}

This work was supported by the Institute of Biotechnology, Urmia University. We are grateful to
Mr. Asghar Aliyari and Mr. Yousef Heidar Sani (Immunology laboratory, Veterinary School of Urmia University), and Mr. Younes Najafi for blood donation. 


\section{Conflict of Interest}

The authors declare that they have no conflict of interest in this work.

\section{References}

1. Kumar V, Abbas Ak, Fausto N, Mitchell R. Cell Injury, Cell Death and Adaptations. Robbins basic pathology. 8 ed: Elsevier, 2007: 7-37.

2. Chernikov V, Belousova T, Kakturskiǐ L. Morphological and biochemical criteria for cell death. Arkh Patol. 2009;72(3):48-54. PMID: 20734836

3. Kroemer G, Galluzzi L, Vandenabeele P, Abrams J, Alnemri
ES, Baehrecke E, et al. Classification of cell death: recommendations of the Nomenclature Committee on Cell Death 2009. Cell Death Differ. 2008;16(1):3-11. PMID: 18846107

4. Peter ME. Programmed cell death: apoptosis meets necrosis. Nature. 2011;471(7338):310-2. PMID: 21412328

5. Ouyang L, Shi Z, Zhao S, Wang FT, Zhou TT, Liu B, et al. Programmed cell death pathways in cancer: a review of apoptosis, autophagy and programmed necrosis. Cell Prolif. 2012; 45(6):48798. PMID: 23030059

6. Mescher AL. the cell nucleus. Junqueira's basic histology: text and atlas. 12 ed: McGraw-Hill, 2010: 97-100. 